DOI: https://doi.org/10.31392/NPU-nc.series9.2020.20.07

UDC: 81.33

Yuliia V. Kravtsova

National Pedagogical Dragomanov University,

Kyiv, Ukraine

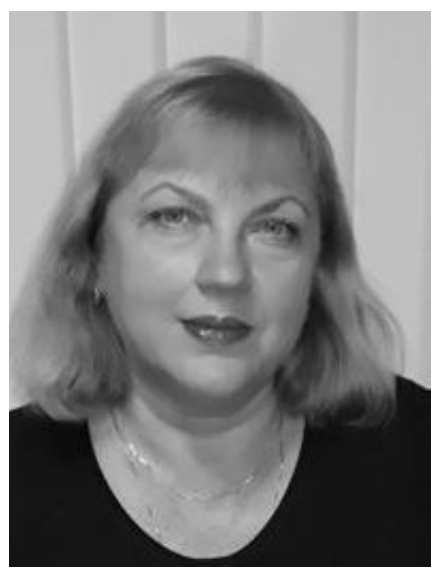

\title{
METAPHORICAL LEXICOGRAPHY: BASIC PRINCIPLES, CURRENT PROBLEMS AND DEVELOPMENT PROSPECTS
}

\section{Bibliographic Description:}

Kravtsova, Yu. V. (2020). Metaphorical Lexicography: Basic Principles, Current Problems and Development Prospects. Scientific Journal of National Pedagogical Dragomanov University. Series 9. Current Trends in Language Development. 20. 91-100. https://doi.org/10.31392/NPU-nc.series9.2020.20.07

\section{Abstract}

The article discusses the basic principles of the lexicographic description of metaphorical nominations, current problems and development prospects of metaphorical lexicography.

Until recently there were no self-dependent descriptions of the metaphor. Metaphorical lexicography as a new direction of vocabulary practice began to actively form in the XXI century. The prerequisites for the emergence of metaphorical dictionaries as a self-reliant lexicographic branch were such stable tendencies as the regular fixation of figurative (metaphorical) meanings of words in explanatory dictionaries, the development of figurative and artistic lexicography, and the creation of ideographic dictionaries.

As a result of the analysis of the developed metaphorical dictionaries their following types were identified: ideographic (thematic), author's (idiolect), explanatory, terminological. The availability of different types of metaphorical dictionaries is determined by the specificity of the metaphor as a language phenomenon and the multidimensionality of its linguistic study.

The following basic principles of Russian metaphorical lexicography have been established and characterized: fixing a metaphor as a heading word; complex structuring of a dictionary entry by introducing new components (indicating the initial meaning, metaphorical model, etc.); adding various comments and marks; the integrative nature of the description, including not only the interpretation of metaphorical semantics, but also other information (cultural, historical, etc.).

The main problem of compiling metaphorical dictionaries is that the metaphor is one of the most productive way of forming meaning and figurative language means, widely used in speech, therefore, it is extremely difficult to establish all the available facts of metaphorization, systematize and describe metaphorical nominations. 
An attempt has been made to predict the prospects for the further development of Russian metaphorical lexicography.

Keywords: metaphor, metaphorical nomination, metaphorical lexicography, metaphorical dictionary, dictionary entry.

\section{Introduction.}

For a long time metaphorics as a special class of language units in the Russian vocabulary didn't stand out, and the lexicographical description of metaphorical nominations was carried out within the framework of the creation of normative explanatory dictionaries ("Explanatory Dictionary of the Russian Language" edited by D. N. Ushakov; "Dictionary of the Modern Russian Literary Language" edited by V. I. Chernyshev; "Dictionary of the Russian language" edited by A. P. Evgenieva; "Dictionary of the Russian language" by S. I. Ozhegov, etc.), in which they were traditionally described as independent figurative meanings or figurative shades of direct and basic figurative meanings in dictionary entries of polysemants. According to G. N. Sklyarevskaya, "almost every polysemous word contains figurative meanings and shades" (Sklyarevskaya, 1993: 26).

The compilers of explanatory dictionaries gradually developed the principles of fixing words, including their figurative (metaphorical) meanings, in these lexicographic sources. The methods of describing metaphorical nominations in different dictionaries are somewhat different, but the basic principles of their lexicographical description (order of placement in a dictionary entry; the presence of interpretation, grammatical, stylistic marks, illustrative material) are generally similar.

Until recently there were no independent descriptions of metaphor in Russian lexicography, although they still occupy an insignificant place in it. Objective difficulties in compiling metaphorical dictionaries lie in the fact that the metaphor is one of the most productive means of sense formation and figurative linguistic means, widely used in speech, therefore, it is difficult to establish all the available facts of metaphorization, systematize and describe metaphorical nominations.

At the turn of the XX-XXI centuries, thanks to the spread of computer technologies and corpus techniques, Russian metaphorical lexicography began to form (A. N. Baranov, Yu. N. Karaulov, N. A. Kozhevnikova, Z. Yu. Petrova, N. A. Turanina and others). "The period of synthesized, complex studies of metaphorical potential in its absolutely full volume has come" (Turanina, 2007: 90).

\section{The Principles of Describing Metaphors in Modern Normative Lexicography.}

The problem of representing metaphors in dictionaries is solved ambiguously, which is associated with some unresolved theoretical issues of semasiology and lexicography. First of all, this is the question of distinguishing between figurative meanings (language metaphors) and figurative word usage (speech metaphors), the selection of metaphorical word usage, etc. Therefore, the criteria for distinguishing similar concepts used in vocabulary practice are important. The methods of lexicographic description of linguistic metaphors were developed by N. D. Arutyunova, L. S. Kovtun, O. N. Laguta, G. N. Sklyarevskaya and others. The fundamental principles of lexicographic description of metaphors were formulated in the works of G. N. Sklyarevskaya $(1988,1993)$ who substantiated the metaphor as a systemic language phenomenon subject to certain patterns of formation and functioning. "Being described in the dictionary, the language metaphor has already been empirically systematized and classified, because the dictionary cannot leave any of its elements outside the systematization" (Sklyarevskaya, 1993: 26).

The lexicographic description of metaphorical nominations, reflecting the features of the collective figurative thinking of native speakers of the Russian language at the present 
stage of its historical development, is still carried out in explanatory dictionaries ("Explanatory Dictionary of the Russian Language" by S. I. Ozhegov, N. Yu. Shvedova; "Russian Explanatory Dictionary" by V. V. Lopatin, L. E. Lopatina; "New dictionary of the Russian language. Explanatory and derivational" by T. F. Efremova, etc.) in accordance with the traditions of normative lexicography.

The basic principles of lexicographical description of metaphorical nominations in modern explanatory dictionaries include the following: clear hierarchization of metaphorical meaning in the structure of a polysemantic word and its corresponding fixation in the dictionary entry; necessary and sufficient interpretation of metaphors; introduction of grammatical and stylistic marks; presenting actual illustrative material demonstrating the functioning of this metaphorical nomination in speech; reflection of various semantic and word-formation connections of metaphors.

\section{Formation of Russian metaphorical lexicography.}

The prerequisites for the emergence of metaphorical dictionaries as self-reliant lexicographic branch were such stable tendencies as the regular fixation of figurative (metaphorical) meanings of words in explanatory dictionaries (D. N. Ushakov, S. I. Ozhegov, N. Yu. Shvedova, V. V. Lopatin, L. E. Lopatina and others), the development of figurative and artistic lexicography (V. V. Vinogradov, G. O. Vinokur, V. P. Grigoriev and others), the creation of ideographic dictionaries (Yu. N. Karaulov, V. V. Morkovkin, O. S. Baranov and others). "Metaphor is a traditional part of linguistic research, but far from a traditional object for lexicography, although some steps in this direction have already been taken" (Makhnitskaya, 2003: 3).

The first self-reliant lexicographic descriptions of Russian metaphors were the dictionaries of A. N. Baranov and Yu. N. Karaulov, developed at the end of the 20th century on the material of political discourse. Later dictionaries appeared on the material of artistic (V. N. Teliya, N. A. Turanina) and medical (A. P. Dyachenko) discourses, as well as ideographic dictionaries of metaphors for certain thematic areas (N. A. Kozhevnikova, Z. Yu. Petrova, E. A. Yurina). However, it should be noted, that in these metaphorical dictionaries language and speech metaphors are practically not differentiated, but illustrative material presented is quoted from fiction and journalistic texts, in which both usual and occasional metaphors are used.

\section{Types of Metaphorical Dictionaries.}

In our opinion, the available metaphorical dictionaries, according to the method of lexicographic description, can be conditionally divided into the following types: ideographic (thematic), author's (idioletic), explanatory, terminological. The emergence of different types of dictionaries of Russian metaphors is determined by the multidimensionality of this phenomenon and the specifics of the language material. Since the end of the 20th century, ideographic dictionaries of metaphors have received the most active development.

\subsection{Ideographic (Thematic) Dictionaries.}

The metaphorical dictionaries of A. N. Baranov and Yu. N. Karaulov "Russian political metaphor (materials for the dictionary)" (Baranov, Karaulov, 1991) and "Dictionary of Russian political metaphors" (Baranov, Karaulov, 1994) contain contexts of using metaphors, characteristic of the Russian political discourse of the perestroika epoch (19851991). According to the observations of the authors, the organic way of thinking, traditional for native speakers of the Russian language, when metaphors, which related to the conceptual spheres "the world of plants", "the world of animals", "the human body", were 
actively used in political speech, was "in the Soviet epoch noticeably supplanted by the mechanistic, rational way of metaphorical understanding of political reality (metaphors of a machine, engine, construction)" (Baranov, Karaulov, 1991: 190). In accordance with the descriptor theory developed by the authors, metaphors in these dictionaries are described in the form of metaphorical models in relation to political realities. For example, the metaphors of the mechanism relate to the state, finance, democracy, glasnost, legislation, the army, etc. The compilers of the dictionary found that in the Russian political discourse of the perestroika epoch, metaphors were used forming only about fifty productive metaphorical models.

The metaphorical model (M-model) in the analyzed dictionaries is a thematic field of significant descriptors. Each descriptor includes hierarchically ordered "trees", - that is generic and species relations are mainly displayed. The authors distinguish M-models of war, sport, game, transport, technology, family relations, fauna, etc., structured in the form of "trees" (Kravtsova, 2018: 99). For example, within the framework of the thematic field, which organizes the metaphorical model "War", the conceptual areas "weapons", "types of military actions", "participants in hostilities", etc. are distinguished, which, in turn, are formed by a set of terminal concepts: "Weapon"-винтовка, меч, динамит, etc. These dictionaries contain a significant corpus of metaphors and describe typical metaphorical models characteristic of the political discourse of the corresponding period.

Ideographic (thematic) dictionaries of metaphors continue to be actively developed based on various materials and fragmentarily describe certain conceptual spheres of Russian metaphorics (N. A. Kozhevnikova, Z. Yu. Petrova, E. A. Yurina and others).

The basic principle for describing metaphorics in "Materials for the Dictionary of Metaphors and Comparisons of Russian Literature of the 19th-20th centuries" by N. A. Kozhevnikova and Z. Yu. Petrova $(2000,2010,2015)$ is, according to the authors' definition, a "thesaurus" principle, in which designations of realities and their figurativemetaphorical correspondences are grouped into semantic fields. The compilers of the dictionary have developed such ideographic areas as "Birds" (Kozhevnikova, Petrova, 2000), "Animals, insects, fish, snakes" (Kozhevnikova, Petrova, 2010), "Plants" (Kozhevnikova, Petrova, 2015). Different issues of "Materials for the Dictionary ..." reflect specific semantic fragments of the figurative system of Russian fiction (metaphors-riddles, genitive metaphors, metaphorical paraphrases, comparisons) and the evolution of this system. Subjects of metaphorization and comparison are subdivided into three main classes: "Human", "Time" and "World around". For example, in the class "Human" the subclasses "Designations of people", "Aggregate of people", "Parts of the human body", "Physical and psychophysical properties and states", "Inner world of a human", etc. are distinguished. When grouping material according to images of metaphorization and comparisons, all kinds of relationships in the semantic fields "Birds", "Animals", "Insects", "Fish", "Snakes" are taken into account. Each class of tropes is described as a set of elements, the structure of which is set by the corresponding semantic fields of direct meanings of words. The most common relationships are generic and species: зверь - волк, лиса, медведь, лев, тигр, конь, собака, etc. This type of relationship also includes the subdivision of animals according to breeds: for example, собака / пес - бульдог, овчарка, пудель, сеттер, такса, etc. When placing the material in the dictionary entry, the names of animals related to sex are also taken into account: бblккорова, баран - овиа, волк-волчица, еtс.

In addition to the principle of the semantic field, the language facts in "Materials for the Dictionary ..." are grouped according to formal syntactic constructions, in which the support words of tropes are used; for example, Чичиков еще раз взглянул на него искоса, когда проходили они в столовую: медведь! совершенный медведь! (N. Gogol). Thus, "Materials 
for the Dictionary ..." demonstrate the main semantic classes of tropes, including metaphors, on subjects and images of metaphorization and comparison; semantic relations in metaphorical fields in combination with the diachronic principle of material presentation make it possible to trace the development of trope classes in the history of the language of Russian fiction.

The "Dictionary of Russian food metaphor" edited by E. A. Yurina (Yurina, 2015, 2017) contains metaphors of the Russian language, that call the phenomenon of reality by analogy with various food products and the processes of cooking and eating food. To preserve the semantic unity of the original image, which served as an analogue of the figurative characteristics of the named objects and phenomenon, the vocabulary material is arranged according to the thematic principle and grouped into lexical and phraseological nests. The arrangement of the material in this dictionary is based on thematic, nesting and alphabetical (inside the nest) principles, for example: 1. Plant products: 1.1. Cereal products, flour and cereal products. 1.2. Fruits. 1.3. Vegetables. 1.4. Berries. 1.5. Mushrooms. 1.6. Nuts. In each subsection lexical and phraseological nests are presented, the top of which is the original food nomination.

The dictionary entry in this dictionary includes the interpretation of the original direct and metaphorical meaning, as well as a linguistic and cultural commentary. The vocabulary presentation of the lexico-phraseological nest opens with a headword with the original gastronomic meaning, motivating a series of figurative nominations, its interpretation and contextual illustration in the following sequence: 1) the original meaning; 2) figurative meanings (language metaphors, semantically derived from the headword; figurative expressions (comparisons, phraseological units, proverbs, sayings), including the original word in an allegorical meaning; words of different parts of speech, derived from the original motivating words and having metaphorical meaning); 3) typical figurative representations inherent in the Russian conceptual figurative system and fixed in the semantics of language units. For example: Fry. <..> I. Cook food under extreme heat, usually in fat or oil without adding water. Иногда болтаешь по телефону с подругами, а бабушка жарит котлетки и подает их прямо в кровать (D. Dontsova. Fish soup). II. 1. Language metaphor. Colloquial. 1. Burn with rays (about the sun). Expressive. Солнце, находясь привычно высоко над горизонтом, жсарило обгорелые плечи (“Around the World"). <...> 3. Fried. Language metaphor. Colloquial. Scandalous, intriguing, attracting everyone's attention (about information, as a rule, of a negative nature, used by journalists). Expressive. У нее сейчас ощущение пустой траты времени, она смотрит на сиену и думает, что, возможно, в это самое время появилось что-то жсареное, скандальное, общеинтересное ("Volga"). <...> III. 1. The process of cooking under the influence of intense heat is figuratively associated with a person's stay in a stuffy and hot room, under the rays of the scorching sun, in very hot air, as a result of which a feeling of discomfort and physical ailment arises. 2. The action of highly heated and hot kitchen objects and equipment, which are used for frying food, is metaphorically projected onto physical processes and phenomena associated with a high degree of intensity (emission of bright light, vigorous actions and movements of a person, shooting a weapon, fast and loud speech ). 3. Heating a product to a high temperature in an oven, in a frying pan, on an open fire during frying is figuratively associated with the influence of negative social circumstances on a person, being in difficult life situations (Yurina, 2017: 38). Consequently, each dictionary entry includes a heading word, its brief grammatical characteristic, an indication of the style and emotional-expressive coloring by means of appropriate marks, the interpretation of the metaphorical meaning of the word or figurative expression, illustrative contexts, linguocultural comments describing collective figurative representations characteristic of the carriers of this linguoculture. 


\subsection{Author's (Idiolect) Metaphorical Dictionaries.}

The first experience of creating an author's dictionary of metaphors was N. A. Turanina's "Dictionary of Metaphors by V. Mayakovsky" (Turanina, 1997). It contains all the poet's metaphors, extracted from the complete collection of his works. "This approach gives a complete picture of the number of author's metaphors (5200 uses, 3257 self-reliant words), part of speech they belong to, lexical and thematic preferences of V. Mayakovsky. $<\ldots>$ At its core, such a dictionary is the vocabulary in which each metaphor is presented in a micro-context" (Turanina, 2008: 199). All metaphors in this dictionary are arranged in alphabetical order. The dictionary definition contains the metaphorized word and a complete list of its corresponding uses in the poet's metaphorical contexts. Examples of metaphorical use of lexemes are arranged in a dictionary entry in chronological order and are accompanied by "output data": the year the metaphor appeared in the poetry of V. Mayakovsky, the volume of the publication, the page on which the metaphor was used. For example, Grow: "растет улыбка. 1915, 1, 99; мысль растет. 1923, 4, 149; растет революция. 1926, 7, 238; расти нашей бодрости. 1927, 8, 328; растет добродушие. 1928, 9, 290" (Turanina, 1997: 117). As the author notes, the dictionary "makes it possible to reveal the evolution of the poet's metaphorical images, the lexical base of metaphors, the combinability of lexemes-components of metaphors, to show a wide range of the author's associations, the figurative model of the world of V. Mayakovsky" (Turanina, 2008: 199). "The Dictionary of Metaphors by Alexander Blok" by N. A. Turanina (Turanina, 2000) was compiled according to the type of "Dictionary of Metaphors by V. Mayakovsky" "in order to identify common and different trends in the development of metaphor in the texts of poets of the early XX century" (Turanina, 2008: 200).

The metaphorical dictionaries, developed on the material of artistic / poetic speech of certain literary trends or a certain period in the development of literature, which reflect the author's metaphors of a number of writers and demonstrating the results of metaphorization on an extensive fragment of the literary process, can also include to author's dictionaries. Thus, N. A. Turanina, more than ten years ago, expressed the idea of creating a "Dictionary of metaphors of Russian poetry of the early 20th century", the purpose of which was to identify the characteristic metaphors of the beginning of the last century, to define traditions and innovations in the creation of metaphorical images in the poetic speech of this historical period. "In such dictionaries, it becomes possible to identify denotations involved in the metaphorical process of several authors, to generalize the use of texts with an abstraction from a specific idiostyle" (Turanina, 2008: 201). However, there is no information on whether this lexicographic project was implemented.

The material for such a dictionary should have been "poetic texts of Russian poets of the early 20th century: A. Blok, S. Yesenin, V. Mayakovsky, A. Akhmatova, N. Gumilyov, I. Annensky, O. Mandelstam, V. Bryusov, N. Gorodetsky, M. Voloshin, K. Balmont, D. Bedny, E. Bagritsky and many other authors, who contributed to the development of Russian poetic speech of this period" (Turanina, 2008: 201). According to the researcher, a dictionary of this type will allow "to present the semantic spheres of metaphors of each individual author, to reveal the variety of thematic layers of vocabulary involved in the metaphorical process, to characterize those types of metaphorization that are not inherent in an individual author, but are characteristic of writers of the same literary direction. $<\ldots>$ It is assumed that this dictionary will consist of two parts. The first part will give a list of metaphors (vocabulary), arranged alphabetically; the second part of the dictionary of metaphors is thought of as a catalog of images of the early 20th century in poetic texts by different authors. The dictionary entry in the first part of the dictionary is based on the 
principles we developed earlier" (Turanina, 2008: 202). Sample dictionary entry: Gold: золото волос (Balmont, 1902); в золоте лучей (Gumilyov, 1905; Voloshin, 1909); золото лип (Bryusov, 1905; Yesenin, 1918); золото солнца (Yesenin, 1914); золото травы (Yesenin, 1914); наше золото - звенящие голоса (Mayakovsky, 1917); золото овса (Yesenin, 1922). An example of the arrangement of the material in the second part of the dictionary: Image of time: Горы времени (Mayakovsky, 1914-15, 1, 121); в снегу времен (Blok, 1908, 3, 110); у времени-хамелеона (Mayakovsky, 1914-15, 1, 131); горами веков (Mayakovsky, 1920, 2, 37); тропь столетий (Bryusov, 1906, 41); время-крот (Mayakovsky, 1929, 8, 134); дуновение веков (Balmont, 1902, 56); ночь времен (Voloshin, 1912, 45); из-за времени гор (Mayakovsky, 1920, 3, 130); через горы времен (Mayakovsky, 1914-15, 1, 75); сумерки времен (Blok, 1910, 3, 18) (Turanina, 2008: 202). Consequently, this dictionary assumes the use of the principles of minimizing the context, which will make it possible to more clearly display the metaphorical meanings, and the rejection of "any definitions that always impoverish metaphorical semantics" (Turanina, 2008: 203). We find it difficult to agree with the said statement, since, in our opinion, it is necessary to strive to reveal a new metaphorical meaning by means of its semantic reconstruction for an adequate perception of the author's intention. By the nature of the presentation of language material, the proposed type of dictionary resembles the well-known "Dictionary of the Language of Russian Poetry of the XX century", edited by V. P. Grigoriev, including contexts from the poems of I. Annensky, A. Akhmatova, A. Blok, S. Yesenin, M. Kuzmin, O. Mandelstam, V. Mayakovsky, B. Pasternak, V. Khlebnikov, M. Tsvetaeva. This dictionary does not provide any interpretation of lexemes acting as head words.

\subsection{Explanatory Metaphorical Dictionaries.}

The author of this article partially realized the idea of creating a dictionary of metaphors, large-scale in terms of coverage of language (speech) facts, in "Materials for a dictionary of metaphors of Russian poetry and prose of the first half of the 20th century" (Kravtsova, 2014: 295-317), but the tasks of our dictionary did not include a strict fixation of all metaphorical contexts from the works of Russian prose- poets (A. Akhmatova, A. Bely, Z. Gippius, V. Inber, M. Kuzmin, B. Pasternak, I. Selvinsky, M. Tsvetaeva). The most important was the identification of various metaphorical nominations, characteristic of Russian literature of this historical period, and the interpretation of their meanings. The interpretations of language metaphors are given in accordance with the explanatory dictionaries of the Russian language, and the interpretations of speech metaphors are given in the author's formulation with the mark "occasional". For example: Wave. 1. About something, moving one after another in a set at some distance; mass appearing or replacing one another in motion. Расплескалась колосьев волна; в волнах ковыли; береза льет волну своих кудрей; травная волна (A. Bely). 2. The movement of something (some mass or fog, smoke, etc.), resembling the movement of a water shaft. Сквозь волны фимиама; холодочка струится волна; в волнах эфира (A. Akhmatova). Волна ветра; волна пара; снежная волна; дуновенье струило прохладу волною; волны тьмы (A. Bely). Волна холода (V. Inber). Ветер сутулит плечи тугой волной; стекает вниз прозрачность теплыми волнами (M. Kuzmin). Волны зноя (B. Pasternak). В желтой волне тумана (Z. Gippius). 3. An unexpected appearance, strong manifestation of smb. feelings or states; mass manifestation of something. Волна радости (Z. Gippius). Смерти черная волна; волны впечатлений (V. Inber). Волна вожделений; в огромной волне любви, теплоты, прямодушия (M. Kuzmin). Горячая волна рвалась из груди (I. Selvinsky). Волна плача (B. Pasternak). 4. occasional. Sudden loud noises from somebody, something. Волна звуков 
(A. Bely). K веселой волне звуков; волна звуков; с волнами дальней музыки; волны песни (Z. Gippius). Прошла волна оващии по залу (V. Inber). 5. occasional. Duration of something, successive succession of events. Времени волна (A. Bely). K волне дней (B. Pasternak). 6. occasional. Something, having a wavy shape, resembling a wave in its appearance. Волны гривы (А. Akhmatova). Волны кудрей (A. Bely) (Kravtsova, 2014: 297). All metaphorical nominations are placed in alphabetical order, their interpretations in dictionary entries are given by the type of interpretations in normative explanatory dictionaries. Illustrative material is given in minimal contexts where the realizable meaning of the metaphorical nomination is most essential. Therefore, the proposed type of dictionary in the way of presenting the material is close to explanatory dictionaries.

\subsection{Terminological Metaphorical Dictionaries.}

Metaphorization, as is known, is one of the productive ways of creating terms (for example, linguistic terms: языковое дерево, языковая семья, словообразовательное гнездо, словообразовательная цепочка, etc.). It should be noted, that a metaphor, forming a new terminological name and becoming the only nomination of a phenomenon, process, etc., loses its imagery and becomes part of lexicalized/genetic metaphors. However, the description of the facts of metaphorization as a way of terminological nomination seems to be significant for identifying characteristic source spheres and establishing typical models of semantic derivation.

Terminological metaphorical dictionaries include the dictionary-reference "Metaphors and terminologically stable expressions in medicine" by A. P. Dyachenko (Dyachenko, 2000), which contains medical metaphors that "are actively used by practitioners of various specialties when describing symptoms, syndromes, diseases and norms" (Dyachenko, 2000: 3). This dictionary contains professional interpretations of each metaphor (клиническая картина, ветвь аорты, кровеносный сосуд, легочный ствол, сонная артерия, еtс.). As the compiler of the dictionary notes, the proposed thematic classifier allows you to get an idea of the terminological apparatus of more than forty branches of medicine.

\section{Prospects for the Development of Metaphorical Lexicography.}

Metaphors represent "a very numerous, diverse and mobile fund, their lexicographic description will continue to be one of the central tasks of vocabulary practice for a long time to come" (Devkin, 2000: 89). Therefore, it is possible to predict the further development of Russian metaphorical lexicography in several directions: 1) active compilation of ideographic (thematic) metaphorical dictionaries the purpose of which is to establish the conceptual spheres-sources of metaphorization; 2) creation of an explanatory dictionary of metaphors for fixing usual metaphor to the fullest extent possible; 3) development of a national metaphorical corpus of the Russian language.

The creation of a national metaphorical corpus of the Russian language is due, on the one hand, to the intensive development of corpus technologies and the emergence of national corpora of different languages (English, Czech, Russian, etc.), and, on the other hand, to the emergence of national metaphorical corpus (Amsterdam Metaphor Corpus, 2010; MetaNet, 2012; Russian-language corpus of conceptual metaphor, 2013). However, some problems are inevitable the formation of electronic resources of metaphor and tools for their automatic processing (A. N. Baranov, Yu. V. Kravtsova, S. B. Kurash, A. D. Plisetskaya and others). These include: a clear justification of the principles and methods of creating a metaphorical corpus; ensuring its representativeness and balance; rational use of national language corpus; selection of basic explanatory, semantic, metaphorical dictionaries and their high-quality online versions; an adequate choice of methods of linguistic (semantic) markup of common 
metaphors; development of identification algorithms in texts of different genres and styles of occasional metaphors, and their interpretation; search for equivalent metaphorical usages in parallel corpuses.

\section{Conclusions.}

The analysis of existing metaphorical dictionaries made it possible to single out the following basic principles of metaphorical lexicography: fixing a metaphor as a head word; complex structuring of a dictionary entry due to the introduction of new components (indication of the motivating meaning, metaphorical model; interpretation of a typical figurative representation, etc.); adding various comments and marks; the integrative nature of the description, including not only the interpretation of metaphorical semantics, but also other information (from history, cultural studies, etc.).

The major problems of metaphorical lexicography are: 1) criteria for the selection of metaphorical material for different types of dictionaries; 2) further development and unification of the principles of the lexicographic description of metaphor in different types of dictionaries; 3) identification of new facts of metaphorization in various discourses and their fragments; 4) adequate interpretation of occasional metaphors; 5) establishment of changes in Russian metaphorical system at different stages of its evolution.

The prospects for the further development of Russian metaphorical lexicography include: continuation of the practice of compiling ideographic (thematic) metaphorical dictionaries; creation of an explanatory dictionary of usual metaphors; development of a national metaphorical corpus of the Russian language. The successful realization of these lexicographic projects will contribute to the effective implementation of research, teaching and translation activities.

\section{References}

Baranov, A. N. (1991). Russkaya politicheskaya metafora (materialy $k$ slovaryu) [Russian political metaphor (materials for the dictionary)]. RAN.

Baranov, A. N. (1994) Slovar russkikh politcheskikh metafor [Dictionary of Russian Political Metaphors]. Pomovskiy i partnyory..

Devkin, V. D. (2000). Ocherki po leksikografii [Essays on Lexicography]. Prometey.

Dyachenko, A. P. (2003). Metafory $i$ terminologicheski ustoychivyye vyrazheniya $v$ meditsine [Metaphors and terminologically stable expressions in medicine]. Novoye znanie.

Kozhevnikova, N. A., Petrova, Z. Yu. (2000). Materialy $k$ slovaryu metafor i sravneniy russkoy literatury XIX-XXvv. Vyp. 1. Ptitsy [Materials for the dictionary of metaphors and comparisons of Russian literature of the XIX-XX centuries. Vol. 1. Birds]. Yazyki russkoy kultury.

Kozhevnikova, N. A., Petrova, Z. Yu. (2010). Materialy $k$ slovaryu metafor i sravneniy russkoy literatury XIX-XXvv. Vyp. 2. Zveri, nasekomyye, ryby, zmei [Materials for the dictionary of metaphors and comparisons of Russian literature of the XIX-XX centuries. Vol. 2. Beasts, insects, fish, snakes]. Yazyki slavyanskikh kultur.

Kozhevnikova, N. A., Petrova, Z. Yu. (2015). Materialy $k$ slovaryu metafor i sravneniy russkoy literatury $X I X-X X v v$. Vyp. 3. Rasteniya [Materials for the dictionary of metaphors and comparisons of Russian literature of the XIX - XX centuries. Vol. 3. Plants]. Yazyki slavyanskikh kultur.

Kravtsova, Yu. V. (2014). Materialy dlya slovarya metafor russkoy poezii i prozy pervoy poloviny XX v. [Materials for the dictionary of metaphors of Russian poetry and prose of the first half of the XX century]. In: Kravtsova, Yu. V. (Ed.) Metaforicheskoye modelirovaniye mira v khudozhestvennom tekste: semantiko-kognitivnyy analiz (pp. 295-317). Izd-vo NPU im. M. P. Dragomanova.

Kravtsova, Yu. V. (2018). Metaphoric Modelling in Modern Linguistics. Scientific Journal of National Pedagogical Dragomanov University. Series 9. Current Trends in Language Development, 18. 95-106.

Kravtsova, Yu. V. (2019). Metaforicheskaya leksikografiya kak novoye napravleniye slovarnoy praktiki. Slovianski movy, 2 (14). 78-90.

Makhnitskaya, E. Yu. (2003). Metafora v sovremennom ekonomicheskom diskurse i printsypy yeyo leksikograficheskogo opisaniya [A metaphor in modern economic discourse and the principles of its lexicographic description]: Thesis' Abstract. 
Sklyarevskaya, G. N. (1988). Yazykovaya metafora v tolkovom slovare: problemy semantiki (na materiale russkogo yazyka) [Language metaphor in the explanatory dictionary: problems of semantics (based on the material of the Russian language)]. Preprint AN SSSR; In-t rus. yaz.

Sklyarevskaya, G. N. (1993). Metafora $v$ sisteme yazyka [Metaphor in the language system]. Nauka.

Slovar russkoy pishchevoy metafory (2015). [Dictionary of Russian food metaphor]: v $2 \mathrm{t}$. Sost. A. V. Borovkova, M. V. Grekova, N. A. Zhyvago, E. A. Yurina. Pod red. E. A. Yurinoy. T. 1. Blyuda i produkty pitaniya. Izd-vo TGU.

Slovar russkoy pishchevoy metafory (2017). [Dictionary of Russian food metaphor]: v $2 \mathrm{t}$. Sost. A. V. Borovkova, M. V. Grekova, N. A. Zhyvago, E. A. Yurina. Pod red. E. A. Yurinoy. T. 2. Gastronomicheskaya deyatelnost. Izd-vo TGU.

Turanina, N. A. (2007). Metaforicheskiy slovar poezii nachala XX v.: problemy i perspektivy. Vestnik Pomorskogo universiteta. Seriya: Gumanitarnye i sotsialnye nauki. 2(12). 90-95.

Turanina, N. A. (2008). Problemy sozdaniya avtorskikh slovarey metafor [Problems of creating author dictionaries of metaphors]. Vestnik Sankt-Peterburgskogo universiteta. Seriya 9. Filologiya. Vostokovedeniye. Zhurnalistika, 4(2). 198-202.

Izd-vo BelGU.

Turanina, N. A. (1997). Slovar metafor V. Mayakovskogo [Dictionary of metaphors V. Mayakovsky].

Turanina, N. A. (2000). Slovar metafor Aleksandra Bloka [Dictionary of metaphors of Alexander Blok]. Izd-vo BelGU. 196 s.

\section{Бібліографічний опис:}

Кравцова, Ю. В. (2020). Метафорична лексикографія: базові принципи, актуальні проблеми та перспективи розвитку. Науковий часопис Національного педагогічного університету імені М. П.Арагоманова. Серія 9. Сучасні тенденціӥ розвитку мов. 20. 91-100. https://doi.org/10.31392/NPU-nc.series9.2020.20.07

\section{Анотація}

У статті розглядаються базові принципи лексикографічного опису метафоричних номінацій, актуальні проблеми та перспективи розвитку метафоричної лексикографії.

Донедавна самостійні описи метафорики були відсутні. Метафорична лексикографія як новий напрям словникової практики почала активно формуватися у XXI cm. Передумовами для виникнення метафоричних словників як окремої лексикографічної галузі стали такі стійкі тендениії, як регулярна фіксачія переносних (метафоричних) значень слів у тлумачних словниках, розвиток фігуративної та художньої лексикографії, створення ідеографічних словників.

У результаті аналізу розроблених словників метафор виділені такі їх типи: ідеографічні (тематичні), авторські (ідіолектні), тлумачні, термінологічні. Поява різних типів метафоричних словників зумовлена спечифікою метафори як мовного явища та багатоаспектністю ї лінгвістичного дослідження.

Виявлено та проаналізовано такі базові принципи російської метафоричної лексикографії: фіксаиія метафори як заголовкового слова; складна структурачія словникової статті иляхом введення нових компонентів (зазначення прямого значення, метафоричної моделі тощо); додавання різноманітних коментарів і позначок; інтегративний характер опису, що включає не тільки тлумачення метафоричної семантики, а й інші відомості (культурологічні, історичні тощо).

Основна проблема укладання метафоричних словників полягає в тому, що метафора є одним із найпродуктивніших способів смислоутворення та широко використовуваних у мовленні образних мовних засобів, тому встановлювати всі наявні факти метафоризаиії, систематизувати й описувати метафоричні номіначії вкрай складно.

Здійснено спробу спрогнозувати перспективи подальшого розвитку російської метафоричної лексикографії.

Ключові слова: метафора, метафорична номіначія, метафорична лексикографія, метафоричний словник, словникова стаття. 